\title{
GÊNERO MEME E FORMAÇÃO DO HIPERLEITOR POR MEIO DA SEQUÊNCIA DIDÁTICA INTERATIVA
}

\author{
THE GENRE MEME AND HYPER-READER FORMATION THROUGH THE \\ INTERACTIVE TEACHING SEQUENCE
}

\section{GÉNERO MEME Y FORMACIÓN DEL HIPERLECTOR POR MEDIO DE LA SECUENCIA DIDÁCTICA INTERACTIVA}

\author{
Maria Jeane Souza de Jesus Silva ${ }^{1}$ \\ Geisa Araújo Dias ${ }^{2}$ \\ Úrsula Cunha Anecleto ${ }^{3}$
}

\section{RESUMO}

Este estudo, de natureza teórico-analítica, problematiza sobre práticas pedagógicas para a formação do leitor na cultura digital. Tem como objetivo discutir sobre o trabalho com o gênero discursivo memes de internet para a formação do hiperleitor nos anos finais do Ensino Fundamental. Como forma de ampliar essa discussão, partiu-se da seguinte questão: como o trabalho com o gênero discursivo meme de internet oportuniza novas práticas leitoras,

\section{Submetido em: 24/07/2020 - Aceito em: 22/09/2020 - Publicado em: 25/01/2021}

\footnotetext{
${ }^{1}$ Mestra pelo Programa de Pós-graduação em Educação e Diversidade, na linha de pesquisa Educação, Linguagens e Identidades (PPED/UNEB). Pesquisadora do Grupo de Estudo e Pesquisa (Multi)letramentos, Educação e Tecnologias (GEPLET/CNPq). Professora de Língua Portuguesa e Língua Inglesa da Educação Básica, Monte Santo, Bahia, Brasil.. E-mail: jeanymped@gmail.com

${ }^{2}$ Graduada em Letras Português / Inglês pela Faculdade de Tecnologia e Ciências e em Pedagogia no Centro Universitário Internacional UNINTER. Especialista em Docência na Educação Básica: Língua Portuguesa pela Faculdade do Sertão Baiano - FASB, em Pedagogia Histórico-Crítica para as Escolas do Campo na Universidade Federal da Bahia - UFBA e, em Gestão Educacional - FASB. Mestranda no Programa de Pós-graduação em Educação e Diversidade (PPED/UNEB) e membro do Grupo de Estudo e Pesquisa em (Multi)letramentos, Educação e Tecnologias (GEPLET/CNPq). Professora de Língua Portuguesa na Educação Básica, Monte Santo, Bahia, Brasil.

${ }^{3}$ Doutora em Educação (UFPB). Mestra em Crítica Cultural (UNEB). Docente no Programa de Pós-graduação em Estudos Linguísticos (PPGEL/UEFS) e no Programa de Pós-graduação em Educação e Diversidade (PPED/UNEB). Professora Adjunta no Departamento de Educação (DEDU/UEFS). Líder do Grupo de Estudo e Pesquisa em (Multi)letramentos, Educação e Tecnologias (GEPLET/CNPq) e do Núcleo de Estudos e Pesquisas da Pedagogia Universitária (NEPPU/CNPq). E-mail: ucanecleto@uefs.br. Feira de Santana, Bahia, Brasil
} 


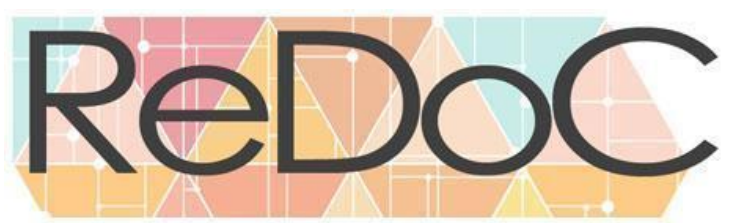

\title{
Revista Docência e Cibercultura
}

oriundas do ciberespaço, visando à formação crítica de alunos dos anos finais do Ensino Fundamental? Para atingir o objetivo e responder à questão central deste estudo, foram propostas oficinas pedagógicas com estudantes do $8^{\circ}$ ano da escola locus, oportunizando a discussão sobre o gênero meme, bem como análise e produção desses textos. Metodologicamente, optou-se pela organização de Sequências Didáticas Interativas (SDI) como meios para a organização e a realização da ação docente. As discussões alicerçaram-se teoricamente nos estudos sobre Gênero discursivo híbrido; Hiperleitor; Sequência Didática Interativa; Meme de internet. O estudo foi fundante para lograr uma aprendizagem experiencial com práticas e saberes do ensino de leitura e de produção textual, em que os memes se figuraram como gêneros discursivos centrais para a ampliação do letramento crítico dos discentes.

PAlAVRAS-CHAVE: Gênero Discursivo Híbrido. Hiperleitor. Sequência Didática Interativa. Memes de Internet.

\begin{abstract}
This study, of a theoretical-analytical nature, discusses pedagogical practices for the formation of readers in digital culture. It aims to debate about working with the internet memes discourse genre to the hyper reader formation in the final years of elementary school. In order to expanding this discussion, the following question was raised: how does the internet meme gender working open up new reading practices from cyberspace, strives for the critical education of students in the ending years of elementary school? In order to achieve the objective and answer the central question of this research, pedagogical workshops were proposed to eighth grade students of the locus school, providing opportunities for discussion about the memes genre, as well as analysis and production of these texts. Methodologically, it was decided to organize Interactive Didactic Sequences (SDI) as a way for organizing and carrying out the teaching action. The discussions were theoretically based on studies on hybrid discursive genre; Hyper-reader; Interactive Didactic Sequence; Internet memes. The study was fundamental to achieve an experiential learning with practices and knowledge of teaching, reading and textual production, in which memes showed up in central discursive genres for the expansion of students' critical literacy.
\end{abstract}

KEYWORDS: Hybrid Discursive Genre. Hyper-reader. Interactive Didactic Sequence. Internet Memes.

\section{RESUMEN}

Este estudio, de naturaleza teórico-analítica, problematiza sobre prácticas pedagógicas para la formación del lector en la cultura digital. Tiene como objetivo discutir sobre el trabajo con el género discursivo memes de internet para la formación del hiperlector en los años finales de la Escuela Primaria. Como forma de ampliar esa discusión, se planteó la siguiente pregunta: ¿cómo el trabajo con el género discursivo meme de internet ofrece oportunidad de nuevas prácticas lectoras, provenientes del ciberespacio, con vistas a la formación crítica de alumnos de los años finales de la Escuela Primaria? Para lograr el objetivo y responder a la cuestión central de este estudio, se propusieron talleres pedagógicos con estudiantes del octavo año de la escuela locus, dando la oportunidad de discusión sobre el género meme, así como el análisis y producción de eses textos. Metodológicamente, se ha optado por la organización de Secuencias Didácticas Interactivas (SDI) como medios para la organización y la realización de la acción docente. Las discusiones se han fundamentado teóricamente en estudios sobre Género discursivo híbrido; Hiperlector; Secuencia Didáctica Interactiva; Meme de internet. El estudio fue esencial para lograr un aprendizaje experiencial con prácticas y saberes de enseñanza de lectura y producción textual, en que los memes se figuraron como géneros discursivos centrales para la ampliación de la alfabetización crítica de los estudiantes.

PAlAbraS ClAVE: Género Discursivo Híbrido. Hiperlector. Secuencia didáctica interactiva. Memes de internet. 


\section{Introdução}

A ampliação de espaços interacionais, oportunizada pela difusão das tecnologias digitais (TD), na atualidade, facilitou o acesso ao conhecimento, rompendo fronteiras físicas e descortinou cenários que apresentam diversas possibilidades de práticas textuais. Ao sujeito leitor, inserido nesse contexto de multiplicidade de linguagens, lhe é conferido participar de novas práticas de leitura atentas ao que é inerente à esfera digital.

Nessa esfera, a interação ocorre por meio da diversidade de linguagem e de modos textuais, tornando-se, assim, multissemiótica (KRESS; VAN LEEUWEEN, 2006 [1996]). O uso dos recursos semióticos nesse espaço tem uma função informativa e crítica, não podendo ser caracterizado, somente, como um adereço na construção dos textos, mas como potencial de sentido que contribui para a formação de um leitor crítico.

Emerge, nesse contexto, a formação de um novo leitor - o hiperleitor - e tal formação constituise como elemento que o torna pleno de autonomia, apto a posicionar-se diante do mundo e da palavra. Esse hiperleitor é calcado no leitor ubíquo (SANTAELLA, 2004), capaz de navegar por diferentes linguagens; é implicado no mundo virtual e se adapta aos novos suportes projetados pelo ambiente multissemiótico de leitura. O hiperleitor "dialoga com uma infinidade de links, designs, linguagens que exigem outras habilidades leitoras, que podem ser ampliadas no espaço escolar" (SILVA; SANTANA; ANECLETO, 2019, p. 28).

Nesse novo cenário digital, a leitura não é mais linear e fechada como, geralmente, ocorre no texto impresso, pois agora possibilita diferentes percursos. Seu trajeto é multilinear e dinâmico, condicionado pela navegação e pela convergência de mídias, apresentando textos com diferentes linguagens, que se constituem de forma híbrida. Dessa forma, desde o surgimento dos novos suportes e estruturas para o texto, especialmente com as tecnologias digitais, procurase compreender os novos leitores e práticas de leitura que as atuais estruturas híbridas e alineares do texto estão fazendo emergir.

Por conseguinte, o leitor do século XXI deve apresentar habilidades de leitura muito distintas daquelas do leitor analógico ou do impresso, já que um tipo de leitor não exclui, mas também não se reduz ao outro. Isso porque características do leitor - contemplativo/meditativo 


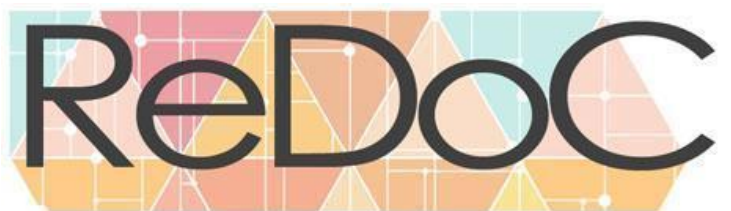

\section{Revista Docência e Cibercultura}

(características do impresso), movente/fragmentado (meios de comunicação de massa) ou imersivo/virtual (mídias digitais) - se entrelaçam, dependendo da necessidade sociocomunicativa de cada sujeito.

Com essa perspectiva teórico-analítica, este artigo tem por objetivo discutir como o trabalho com o gênero discursivo memes de internet oportuniza a formação do hiperleitor nos anos finais do Ensino Fundamental. Tenciona refletir sobre características desse gênero no contexto da cultura digital, a partir da realidade textual de alunos da Educação Básica, visando ampliar práticas de leitura desses estudantes, para que utilizem, de forma crítica e responsiva, gêneros da esfera digital.

Metodologicamente, partimos do dispositivo Sequência Didática Interativa (SDI) como meio para a construção de informações e, ao mesmo tempo, planejamento para a realização de práticas de ensino. No aspecto teórico, a concepção do memes é ancorada nos estudos dos gêneros discursivos, que se constituem de forma híbrida e multissemiótica ${ }^{4}$. A leitura desse gênero exige uma experiência de letramento completamente diferente da que ocorre no habitual, pois é preciso saber ler as referências culturais embutidas, a mensagem implícita que o conteúdo apresenta, o controle de informação, entre outros elementos.

\section{Construto teórico: concepção de gênero discursivo}

A gênese do termo 'gênero' sempre foi bastante utilizada pela retórica e pela teoria literária; mas, em Mikhail Bakhtin - filósofo da linguagem russo, que se dedicou aos estudos da linguagem e da literatura no início do século XX -, esse termo é utilizado em sentido mais amplo, referindo-se, também, aos textos que empregamos nas situações cotidianas de comunicação. Na concepção bakhtiniana, a que orienta este estudo, há três características

\footnotetext{
${ }^{4}$ Quando falamos em gêneros discursivos multissemióticos, evidenciamos a possibilidade de trabalho com gêneros compostos por várias linguagens (modos e semioses). Isso significa que, nas nossas salas de aula, é importante dar lugar a gêneros que combinam diferentes modalidades, tais como as linguagens verbal (oral e escrita), visual, sonora, corporal, digital etc.
} 


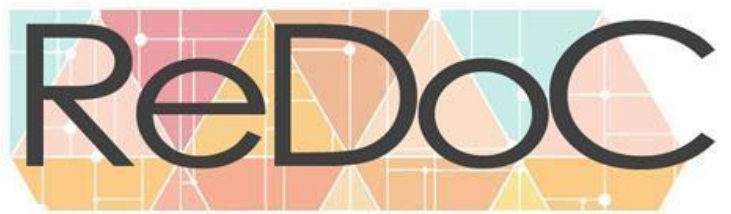

\section{Revista Docência e Cibercultura}

coexistentes nos gêneros do discurso: conteúdo temático, estilo verbal e construção composicional.

O conteúdo temático se refere ao objeto semântico do discurso; o estilo verbal, à seleção dos recursos linguísticos e gramaticais da língua; a construção composicional refere-se a características formais do texto. Dessa forma, entendemos que os gêneros não significam somente aspectos estruturais, mas a articulação de propósitos comunicativos, temáticos e estilísticos (BAKTHIN, 2003) para a construção de sentido. Como apresenta o autor, quando estamos numa situação de interação verbal, a escolha do gênero não é completamente espontânea, pois leva em conta um conjunto de coerções dadas pela própria situação de comunicação: quem fala, sobre o que fala, com quem fala, com qual finalidade.

No Brasil, a concepção de gêneros discursivos passou a ser abordada nas atividades pedagógicas a partir da década de 80, a fim de dar conta da produção textual na escola, trazendo um enfoque sócio-interacionista ao tema. A implementação dos Parâmetros Curriculares Nacionais (PCN), em 1997, trouxe essa preocupação para o ensino básico, propondo o texto como unidade básica para o ensino de Língua Portuguesa e os gêneros discursivos não se desvinculam dos textos.

Nesse contexto, os gêneros discursivos estão interligados a toda diversidade das situações de comunicação, pois os textos não são independentes das práticas sociais e discursivas em que são construídos. Entendemos como práticas sociais o conjunto de ações (ou atividades) que uma comunidade estabelece historicamente como organizadora de seu modo de viver. Práticas discursivas são os comportamentos linguísticos por meio dos quais essas práticas sociais surgem e se mantém.

É possível perceber que os memes de internet se constituem como uma prática textual discursiva, que surge de contextos sociais vinculados às tecnologias digitais. Assim, os memes, enquanto gêneros discursivos, são “[...] tipos relativamente estáveis de enunciados" (BAKHTIN, 2003, p. 262), que apresentam conteúdo temático diversificado, estilo textual verbal e não verbal, a partir de diferente composição semiótica. Esse gênero, característico da cultura digital, já se tornou familiar aos alunos de muitas fases de ensino. Dessa forma, ao 


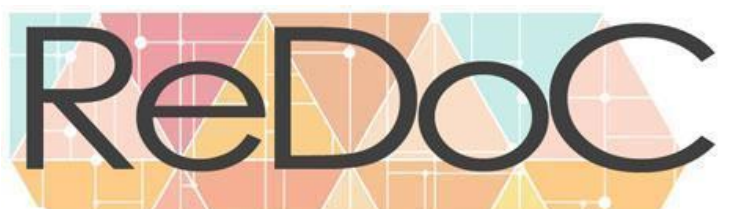

\section{Revista Docência e Cibercultura}

trabalhar com esses textos na sala de aula, esperamos desenvolver capacidades inerentes ao processo de leitura e de produção textual nos espaços virtuais, nos quais os alunos participam diariamente, sem que exista um abismo entre o que se trabalha na escola e as vivências desses sujeitos.

Nesse sentido, parece-nos urgente problematizar o uso de artefatos digitais e suas possibilidades textuais e alinhar a proposta de ensino a um currículo que possa auxiliar a implementação de um projeto educativo que forme o sujeito leitor crítico, inclusive para as mídias digitais, respeitando singularidades e diversidades desses alunos, enquanto seres culturais e letrados. Esses artefatos estão presentes na vida das pessoas de diferentes formas, espaços, tempos e necessidades.

No entanto, incorporar as tecnologias digitais à educação não se trata de utilizá-las somente como meios ou suportes para promover atividades educacionais técnico-instrumentais ou para despertar o interesse dos alunos; significa, sobretudo, proporcionar o desenvolvimento de competências e de habilidades relacionadas ao uso crítico desses meios em diversas práticas sociais, dentre elas as textuais-discursivas. Para isso, torna-se importante a realização de ações pedagógicas que potencializam a formação do hiperleitor crítico, a partir dos gêneros discursivos híbridos, entre eles memes de internet.

\section{Gênero discursivo híbrido memes de internet}

Os memes de internet são um gênero discursivo potencializado pelo ciberespaço. Constituemse por natureza híbrida e apresentam, paralelamente, convergência de linguagem e manifestações culturais, tornando-se textos híbridos. Sobre essa questão, Santaella (2001) se refere ao hibridismo como sendo uma "mistura" ou um "cruzamento" entre modalidades textuais/de linguagem diferentes. Nessa perspectiva, a autora acrescenta que "quanto mais cruzamentos se processarem dentro de uma mesma linguagem, mais híbrida ela será" (SANTAELLA, 2001, p. 379).

Então, é relevante que as instituições educativas dialoguem com a diversidade de textos que circulam socialmente e que fazem parte do universo de leitura de seus alunos, valorizando diferenças culturais e diversidade de práticas letradas. Dos sujeitos atuantes no ciberespaço, 


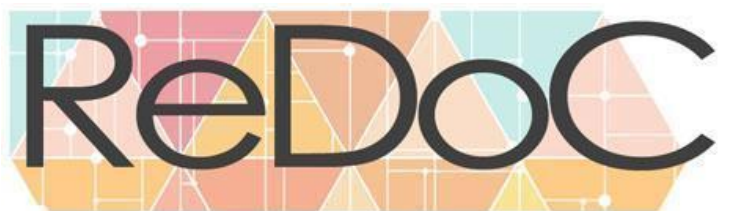

Revista Docência e Cibercultura

esperamos que eles sejam protagonistas na construção de conhecimento, levando em conta o caráter hipertextual ${ }^{5}$ dos textos que povoam esse espaço.

O ciberespaço apresenta rompimento com limites de espaço-tempo, tornando difícil distinguir o que é público do que é privado, o que é próprio do que é comum, o que é subjetivo do que é objetivo (LÉVY, 1996). Então, a virtualização do texto - processo que acontece no ciberespaço - amplia os modos como ocorrem a responsividade, a colaboração e a cooperação nas ações mediadas pelas TD.

Partindo da assertiva de que os gêneros discursivos favorecem a interação entre os sujeitos, também no ciberespaço, é necessário que professores, principalmente os de língua materna, sistematizem práticas de linguagem para que haja uma progressão no domínio dos gêneros socialmente circulantes, trazendo-os para o trabalho em sala de aula. Nessa medida, oportunizar abordagens que colocam textos presentes na cultura digital em foco como objeto de ensino se constitui em uma oportunidade de reflexão acerca da comunicação humana e de meios para a sua materialização.

Tratando especificamente sobre os memes de internet, a forma híbrida desses textos é transformadora e faz com que esse seja um dos "novos escritos" (ROJO, 2013) que reverberam em outras formas discursivo-interacionais. $\mathrm{O}$ termo meme originalmente foi criado e usado na teoria do biólogo Richard Dawkins, em 1976, através de seu livro “The Selfish Gene” (O Gene Egoísta). O etólogo, ancorando-se na teoria da evolução das espécies, comparou a evolução cultural com a evolução genética. Os memes, então, seriam o gene da cultura ao serem disseminados pelas pessoas inseridas em contextos sociais (RECUERO, 2009) e sociocomunicativos.

Ao tratar desse gênero, é importante destacar que a expressão memes de internet é utilizada para caracterizar uma ideia ou conceito, que se difundiu na esfera digital, rapidamente. Assim, podem ser uma frase, link, vídeo, site, imagem, entre outros, os quais se espalham por

\footnotetext{
${ }^{5}$ Hipertexto, para Lévy (1993, p. 33), “é um conjunto de nós ligados por conexões. Os nós podem ser palavras, páginas, imagens, gráficos ou partes de gráficos, sequências sonoras, documentos complexos que podem ser eles mesmos hipertextos. Os itens de informação não são ligados linearmente, como uma corda com nós, mas cada um deles, ou a maioria deles, estende suas conexões em estrela, de modo reticular".
} 


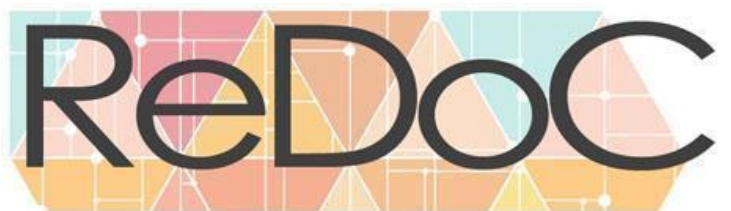

\section{Revista Docência e Cibercultura}

intermédio de e-mails, blogs, sites de notícia, redes sociais, hashtags, aplicativos de mensagens e demais meios de interação virtual entre as pessoas.

Para Dawkins (1976), ao caracterizar o termo meme, não o considera como metáfora para a transmissão de ideias; mas 'estruturas vivas' que residem no cérebro; isto é, eles compreendem uma estrutura física na rede neural de cada pessoa. Também, nos lembram Lankshear e Knobel (2006, p. 211) que "memes são padrões contagiosos de informações culturais. Informações que são transmitidas de mente para mente que moldam e propagam as principais ações e mentalidade de um grupo social".

Dessa forma, entendemos que os memes são oriundos de diversos eventos discursivos que fomentam conteúdos temáticos e têm origem na convergência de mídias e estilos textuais; podem rememorar outros memes (e outros gêneros), assim como modalidades textuais, tornando-se híbridos na construção composicional. Por isso, a leitura desse gênero pode ser desafiadora para alguns, tanto pela característica heterogênea dos textos somada à carga cultural que carregam, como pelo âmbito em que os textos circulam (o ciberespaço) e pelas características intertextuais/hipertextuais que evocam.

Além disso, é fundante destacar que o trabalho com práticas de leitura, a partir de uma diversidade de gêneros discursivos, contribui de forma significativa e colaborativa para que aprendentes possam fomentar o letramento crítico nas práticas sociais e ciberculturais, visando à hiperleitura como prática social que mobiliza agentes para que possam agir textualmente no mundo.

\section{Letramento crítico e formação do hiperleitor}

As contribuições do letramento numa vertente crítica, a partir de Paulo Freire no Brasil e no Chile na década de 70, fizeram emergir a concepção de leitura como prática social - e não apenas como domínio do código escrito. Em Pedagogia da Autonomia - Saberes necessária à prática Educativa, por exemplo, o autor enfatiza a necessidade de uma reflexão crítica sobre a prática educacional, sem a qual a teoria pode emergir apenas em discurso e a prática uma reprodução alienada, sem questionamentos. 
Então, conforme Freire (1996, p. 15), "formar é muito mais do que puramente treinar o educando no desempenho de destrezas"; é respeitar saberes individuais e locais numa perspectiva crítica da realidade em que está inserido, e isso só será possível mediante uma formação ética dos educadores em seu 'ser' e 'fazer' pedagógico. Esse saber pedagógico requer acolhimento, competência profissional e, entre tantas outras coisas, escutar as vozes que ecoam dos alunos.

Para Takaki (2012), letramento crítico assume linguagem, identidade, conhecimento, cultura, poder, ensino e aprendizagem e realidade como noções que se modificam. Essas noções se apresentam ideologicamente incipientes, motivo pelas quais estão sujeitas às constantes interpretações. Dessa forma, no letramento crítico, a construção de sentidos requer compreender os aspectos culturais, históricos e sociais que estão por traz dos discursos que lemos; para ampliar esse tipo de letramento, os docentes precisam despertar nos estudantes a percepção de sentido do contexto de produção e de autoria.

Nesse modelo de letramento, educador e educando são convidados a repensar seus papéis enquanto sujeitos sociais, leitores, consumidores e produtores de conhecimento. Novas práticas sociais de letramento demandam interlocutores ainda mais críticos e conscientes dos processos discursivos de significação, como apontam Cope e Kalantzis (2006), ao considerar que as tecnologias digitais exigem novos letramentos.

Em sala de aula, os professores podem partir dos letramentos que os alunos/as já possuem, das suas culturas locais, e ampliar esses letramentos com os das culturas valorizadas e institucionalizadas pela escola, com foco numa metodologia que contemple as vivências desses estudantes. Imbuídos dessa ótica, vê-se que há infinitas possibilidades pedagógicas capazes de contribuir com práticas de leitura (e de escrita) e, desse modo, diversificar e ampliar esses letramentos na produção colaborativa com as TD, fortalecendo, nesse caso, a formação do leitor crítico na cultura digital, ou seja, o hiperleitor.

Nesse cenário, destaca-se que o perfil dos interlocutores, enquanto sujeitos de criticidade, ganha espaço e considera-se a denotação dada a tal criticidade. Monte Mór (2015) apresenta uma 
noção de crítica utilizando o termo critique associada ao Letramento, conferindo-lhe um caráter crítico.

\footnotetext{
No letramento crítico, a noção de crítica se refere à definição de critique e possivelmente a de crítica ideológica, considerando-se que a crítica remete a uma vivência social, a uma reorganização do conhecimento e a uma autoria nos sentidos construídos pelo leitor, espectador, interlocutor, pessoa, enfim, cidadão. (MONTE MÓR, 2015, p. 43).
}

A autora enfatiza sobre o desenvolvimento da percepção crítica, que está imbricada na teoria dos Letramentos (entre eles, o Letramento Crítico) e chama a atenção para a necessidade de considerá-los no ambiente escolar. Ressalta-se que o chamado Letramento Crítico compreende a consciência crítica como uma atividade a ser desenvolvida nas práticas sociais.

Neste contexto, a formação do hiperleitor constitui-se como resultado do letramento crítico, ao oportunizar espaços de autonomia para o leitor no contexto virtual. O trabalho que dá visibilidade a essa percepção associada às práticas letradas no trato com o texto transcende sua função mecânica; ademais, aliado às práticas no ciberespaço, oportuniza a construção do empoderamento textual e discursivo do sujeito, por outra concepção de espaço-tempo.

Ainda a respeito da abertura à percepção crítica dada ao texto, Monte Mór (2013) nos aponta a contribuição do pensamento de Ricoeur (1978). Para a autora, o sujeito se engaja em exercícios hermenêuticos por meio de 'suspeita' (RICOEUR, 1978). Essa prática problematiza interpretações historicamente herdadas superando sentidos construídos sócio-historicamente, nos moldes convencionais, rompendo com competências tecnicistas em busca da ampliação da capacidade crítico-interpretativa e da reconstrução de sentidos dos hiperleitores.

Com efeito, é importante ressaltar que os educadores, ao engajar-se nesse exercício hermenêutico, precisam atentar-se às reconfigurações da leitura no ciberespaço, visto que essa imersão repercutirá em suas práticas educativas e na promoção/construção da aprendizagem dos alunos. Assim, o letramento crítico envolve a leitura da palavra e do mundo de modo menos ingênuo visto ser uma prática que pressupõe questionamentos e reapropriação de sentidos, convocando o leitor a ir além de uma leitura supostamente neutra da realidade. 
O valor dado à hermenêutica colocada no plano do "pensar", da reflexão; "traz para o centro da discussão uma atitude e um modo de ser do leitor, neste caso, do hiperleitor" (TAKAKI, 2012, p. 70). Essas contribuições estão conectadas na complexidade dos letramentos na era digital, na busca da compreensão de como esses leitores constroem sentidos aos textos multiletrados. Essa ação nos interessa porque buscamos formar um perfil de leitor aprendiz que duvida, mediatizado pela reflexão, e constrói novas percepções da realidade manifestadas pela linguagem.

É necessário, então, reconhecer a relevância de estratégias utilizadas nos ambientes digitais que fomentam práticas letradas, visto que são repletos de recursos semióticos das redes e conexões e promovem a informação, a pesquisa, a socialização, o contexto e as interações entre os alunos. Nesse sentido, “[...] é preciso acompanhar consciente e deliberadamente uma mudança de civilização que questiona as formas institucionais, as mentalidades, a cultura dos sistemas educacionais e os papéis de professor e de aluno." (LÉVY, 1999, p. 172).

Dessa forma, a partir de referenciais teóricos que balizam as TD e das diferentes inquietações que motivaram este estudo, esperamos o rompimento de percepções acríticas e verticalizadas em que a escola, por vezes, limita-se ao utilizar práticas textuais que desconsideram características dos hiperleitores; propomos que o educador descortine e acolha o potencial dos ambientes digitais que surgem com as novas mídias e novos gêneros discursivos, dando ênfase à questão da capacidade crítico-interpretativa da leitura para além do espaço escolar. Para esse movimento didático-pedagógico, optamos pelo trabalho com sequência didática interativa, tendo como horizonte o círculo hermenêutico dialético.

\section{Sequência didática interativa e o círculo hermenêutico dialético}

Para atender aos objetivos da ação didática com o gênero memes de internet, selecionamos a Sequência Didática Interativa (SDI) como dispositivo pedagógico, a partir da Metodologia Interativa (OLIVEIRA 2012), que parte da concepção do Círculo Hermenêutico Dialético (CHD), definido por Oliveira (2012, p. 62) como 
[...] um processo de construção e reconstrução da realidade de forma dialógica através de um vai e vem constante (dialética) entre as interpretações e reinterpretações sucessivas dos indivíduos (complexidade) para estudar e analisar um determinado fato, objeto, tema e/ou fenômeno da realidade.

Situando-se no tempo e no espaço, a sequência didática, oriunda da França no início do anos de 1980, objetivava melhorar o processo de ensino da língua materna, sendo uma proposta para sair de um ensino fragmentado do idioma francês em que se trabalhava conteúdos de forma separada, sem conexão, a exemplo de ortografia, sintaxe e cada categoria da gramática. Somente a partir de 1990, a sequência didática começou a fazer parte da ação cotidiana do professor no Brasil, por meio de estudos de textos, utilizando a teoria dos gêneros do discurso. De acordo com Oliveira (2012), a Metodologia Interativa parte da concepção do CHD, que tem a dialogicidade como eixo condutor. Para a aplicação da SDI, foram necessários seguir alguns passos básicos, tais como: a escolha do tema, o conteúdo a ser estudado, síntese dos conceitos estudados ou síntese geral (definição). A SDI aqui proposta teve a finalidade de promover um novo conhecimento associando teoria e prática; ou seja, o discurso e a materialização dos textos com base na potencialização crítico-discursiva dos sujeitos colaboradores. Dessa forma, a SDI representou, neste estudo,

[...] uma proposta didático-metodológica que desenvolve uma série de atividades, tendo como ponto de partida a aplicação do Círculo Hermenêutico Dialético para identificação de conceitos/definições, que subsidiam os componentes curriculares (temas), e que são associados de forma interativa com teoria(s) de aprendizagem e/ou propostas pedagógicas e metodológicas, visando a construção de novos conhecimentos e saberes (OLIVEIRA, 2013, p. 43).

Justifica-se a escolha desse dispositivo para subsidiar os encontros com os estudantes na realização da oficina pedagógica (descrita na próxima seção) por facilitar o diálogo entre docente e discente, bem como entre alunos e alunos, presumindo uma relação dialógica mútua, novas produções autorais de conhecimentos e saberes colaborativos. Dessa maneira, é importante entender que a interpretação de fatos, fenômenos, conceitos e definições fazem parte de um movimento dialético, ou seja, um vai e vem de interações. Daí porque concebemos a metodologia interativa como um processo hermenêutico-dialético e, por assim entendê-la, 
procuramos fazer um desdobramento dessa metodologia como meio didático no contexto de sala de aula.

\section{Oficina pedagógica: trabalhando com memes de internet}

As oficinas pedagógicas tencionaram potencializar o letramento crítico dos alunos ao lerem e produzirem o gênero discursivo memes de internet. Foi realizada a partir da Sequência Didática Interativa, levando em consideração a formação do hiperleitor. Por meio da dinâmica do CHD, os estudantes puderam apresentar percepções individuais sobre o gênero que serviu de base para a prática de hiperleitura neste estudo. Foi possível explorar a temática, estilo e estrutura da composição dos memes sugeridos, a exemplo do apresentado a seguir, intitulado é verdade esse bilete $^{6}$. Para a análise do texto, foram feitos os seguintes questionamentos: i) Como costumam compartilhar memes: por meio de aplicativos de mensagens ou redes sociais? ii) Vocês já construíram ou reproduziram algum 'meme de internet'? Qual foi a finalidade? iii) O que vocês acham do meme "É verdade esse bilete"?

Figura 1: Meme "É verdade esse bilete".

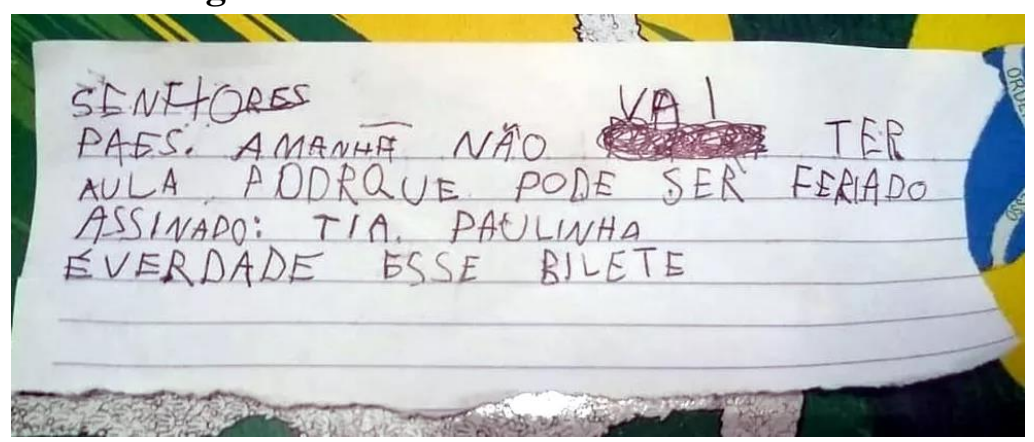

Fonte: http://www.museudememes.com.br/sermons/e-verdade-esse-bilete/. Acessado em: 17 abr. 2020.

Conforme os interlocutores, todos eles já produziram algum tipo de meme, cujas finalidades foram para brincar, informar, criticar e zoar. A “zoeira” é uma das principais características que são apresentadas nos relatos. Em relação ao meio em que mais utilizam para compartilhar os

\footnotetext{
${ }^{6}$ Disponível em: http://www.museudememes.com.br/. Acessado em: em 17 abr. 2020.
} 


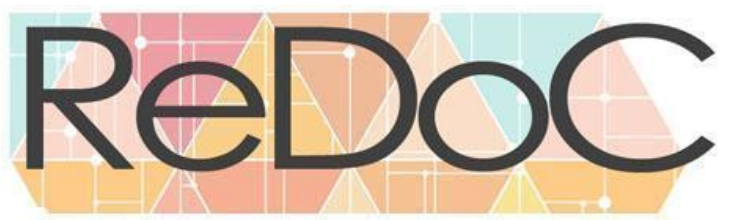

\section{Revista Docência e Cibercultura}

memes, as narrativas demonstram que a rede social Facebook e o aplicativo de mensagem WhatsApp lideram os compartilhamentos; o Instagram aparece como a terceira opção de acesso.

As redes sociais são um dos elementos centrais para a inserção dos jovens no ciberespaço, e a preferência por uma ou outra rede social tem relação, como afirmaram os alunos, com aqueles que pertencem ao círculo de convívio offline. Como os usuários se conectam ao público, a recepção, a visibilidade, a interação são fatores determinantes para que os sujeitos se mantenham ativos na rede (RECUERO, 2009).

Ao apresentar as análises do bilhete aos discentes no consenso coletivo, se sobressaíram os termos "mentira inocente" e "assinatura fake" como elementos relevantes no texto. Essas respostas nos chamaram a atenção: primeiro, porque os alunos se referiram ao bilhete de maneira crítica, sinalizando que uma mentira inocente pode gerar conflitos; segundo, porque os sujeitos se referem à "assinatura fake" como um problema. Nesse momento, foi possível considerar o fator de interação social do CHD, possibilitando que o indivíduo interpretasse, complementasse, observasse e reconstruísse seus argumentos e suas opiniões a partir da interação com outros sujeitos (OLIVEIRA, 2012), como podemos observar nos fragmentos:

Dá pra perceber que no bilhete há uma mentira inocente. Além do menino ter 5 anos de idade, a mensagem, os erros de escrita nos revelam a verdade (@MARVIN7, 2019).

Eu acho esse bilhete muito engraçado, inclusive foi o melhor meme de 2018. Já fiz umas réplicas dele para zoar sobre o crush. Mas não existe mentira pequena nem grande, o poder que a imagem tem e o contexto é o que pode gerar conflito (@NEVASCA, 2019).

Eu achei engraçado, dá pra entender que ele não queria ir pra escola, o problema é ele assinar por outra pessoa, no caso da professora, assinatura fake (@MEMEDROID, 2019).

Vi muitas postagens com mentiras sem pé nem cabeça, por conta do bilhete (@NeXuSs, 2019).

\footnotetext{
${ }^{7}$ As escolhas dos nicknames foram feitas por meio de um convite durante as tertúlias dialógicas digitais, e os fragmentos narrados são recortes de pesquisa de mestrado de uma das autoras do artigo, aprovada pelo Comitê de Ética de Pesquisa, de uma universidade pública do estado da Bahia. Número do CAAE: 3.691.915.
} 
A partir dessas interlocuções, os alunos demonstraram conhecimento, mesmo que de forma não problematizadora, em alguns momentos, sobre a funcionalidade e a concepção do gênero memes de internet. Ao apresentar que "Vi muitas postagens com mentiras sem pé nem cabeça, por conta do bilhete" (@NeXuSs, 2019), evidencia uma importante característica da funcionalidade do gênero: a fecundidade (RECUERO, 2009). Dessa forma, os memes considerados relevantes e/ou interessantes são copiados e reestruturados em relação à linguagem, semioses, modalidades etc., para atender a necessidades sociocomunicativas.

Para Alves Filha (2018), essa característica dos memes, fecundidade, dá origem ao tipo epidêmico: aquele que se propaga com maior intensidade. O meme "É verdade esse bilete", como destacado por @Nevasca (2019), por ter sido tão propagado, tornou-se um meme muito conhecido, sendo, assim, replicado (“Já fiz umas réplicas dele para zoar sobre o crush”) e foi considerado o melhor meme de 2018.

Entretanto, para além de se reconhecer características do gênero discursivo, a leitura do meme supracitado também oportunizou discussões sobre valores morais seguidos pela sociedade, dentre eles o falar a verdade ou não. Isso representa uma das funcionalidades do gênero: enunciados portadores de valores e discursos sociais (ALVES FILHA, 2018). Sendo assim, “O criador dos memes manifesta nos enunciados seus posicionamentos discursivos, relacionados a aspectos sociais, culturais e históricos que são materializados através de linguagem multimodal e multissemiótica" (ALVES FILHA, 2018, p. 65).

No meme supracitado, os hiperleitores destacaram o caráter da não verdade exposto no texto: "Dá pra perceber que no bilhete há uma mentira inocente. Além do menino ter 5 anos de idade, a mensagem, os erros de escrita nos revelam a verdade" (@MARVIN, 2019).Para ele, a questão da falta de verdade relatada no texto diz respeito a uma travessura de criança, quando não deseja cumprir a alguma norma e/ou realizar atividades cotidianas obrigatórias. Alguns aspectos denunciam que o bilhete escrito pelo primeiro autor não poderia ser de uma instituição de caráter formal, como a escola: a mensagem foi apresentada com desvios linguísticos referentes à norma culta da língua.

Entretanto, apesar de considerar o bilhete que motivou o meme engraçado e com uma certa dose de humor (outra característica atribuída a alguns memes), @Nevasca (2019) destaca: "Mas 


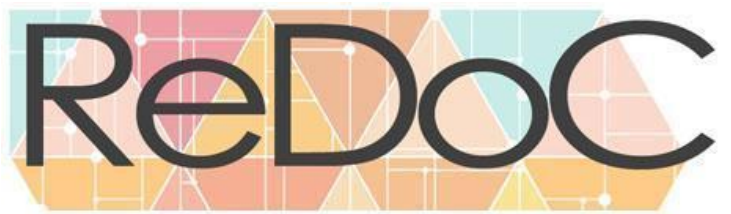

\section{Revista Docência e Cibercultura}

não existe mentira pequena nem grande, o poder que a imagem tem e o contexto é o que pode gerar conflito ". Ou seja: o bilhete supostamente teria sido enviado por uma agência formal de ensino (escola), que representa uma imagem social de "mensagens verdadeiras". Também, a forma de composição do gênero (chamadas aos pais - "Senhores Paes"; conteúdo sobre suspensão de aula; assinatura da professora) faz parte das correspondências cotidianas enviadas pela escola aos pais e/ou responsáveis pelos alunos. Mas a forma como o bilhete foi escrito é que denuncia não se tratar de uma mensagem verdadeira. Então, para @ Nevasca (2019), utilizar esse recurso do texto para gerar memes pode ser até divertido; no entanto, dependendo do entendimento do interlocutor, pode contribuir para propagação de mensagens falsas.

No decorrer da oficina, discutimos sobre as potencialidades dos memes em termos de narrar o cotidiano, dinamizar relações, acionar o humor etc., numa perspectiva de aprendizagem interativa (LEMKE, 2010). Após as discussões sobre o texto, os alunos foram orientados à elaboração de outros memes, a partir do modelo original, dando ênfase, nesse momento, à fidelidade do gênero: capacidade de gerar cópias com maior semelhança (RECUERO, 2009).

Figura 2: Memes recriados a partir do 'bilete'

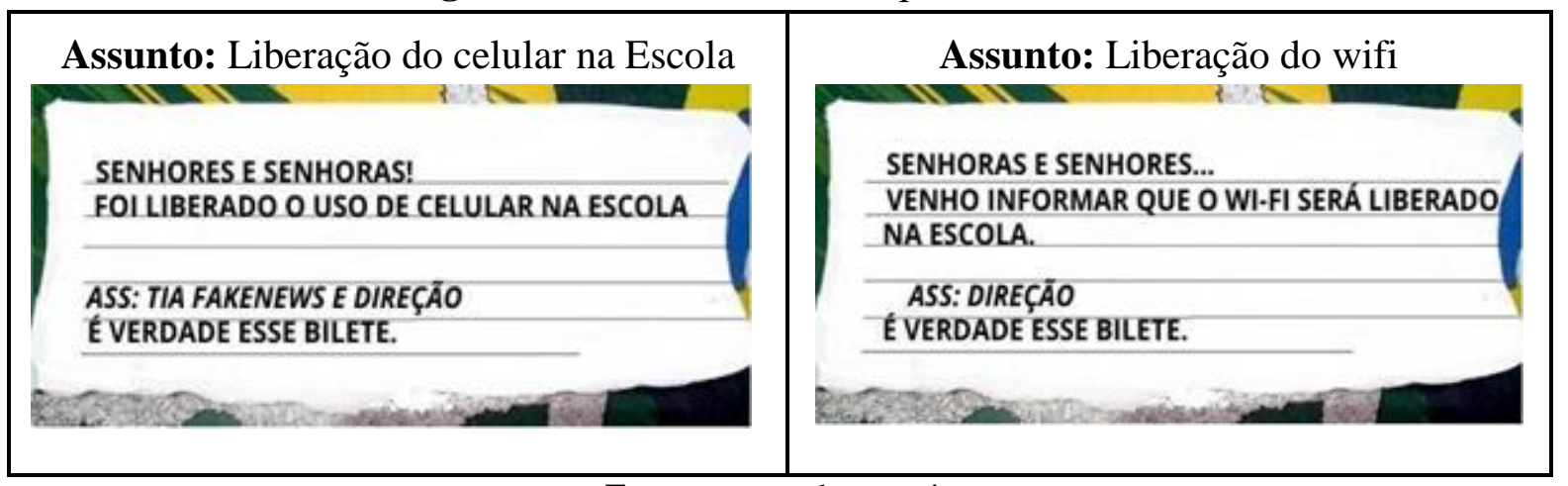

Fonte: acervo da pesquisa

O primeiro e o segundo memes apresentam como conteúdo a problematização do uso do celular ligado à rede de wifi em sala de aula. No Brasil, o uso do celular ou smartphones como meio pedagógico ainda é esporádico. Esses artefatos digitais estão presentes na vida das pessoas de diferentes formas, espaços, tempos e necessidades. No entanto, nem sempre fazem parte de práticas educativas no espaço escolar. 
No cerne da produção, é possível inferir que esse meme/bilhete, de certa forma, é um 'grito' que ecoa nas vozes dos estudantes. Ouvimos a todo tempo, por parte de pais e professores, que os alunos não querem estudar, que só pensam em celular e o seu uso é uma forma de distração, o que gera déficit de atenção, problemas de socialização, resultantes da preferência por contatos e relacionamentos virtuais, entre outros. Diante disso, presumimos que uma educação reflexiva necessita, a um só tempo, ser responsiva aos usos das múltiplas linguagens e tecnologias que (re)desenham as performances na cultura digital e propiciar o posicionamento crítico sobre esses usos.

Maciel e Takaki (2011, p. 64) sugerem que os memes podem ser usados para incentivar os estudantes a questionarem conceitos únicos e generalistas dos textos, se usados pelos docentes para

[...] deflagrar discussões maiores para o entendimento das diferenças na sociedade, mas também servem de estímulo para criação e recriação, como tarefas pedagógicas que ampliam a prática de línguas, propiciando autoconfiança, a autoria multimodal e a crítica dos aprendizes.

Como dado que corrobora com o que foi citado, visualizamos um meme/bilhete que traz em sua essência um assunto que está muito em voga - o fenômeno das "fake news" (em português, notícias falsas), apresentado na figura 3.

Figura 3: Memes recriados a partir do 'bilete'

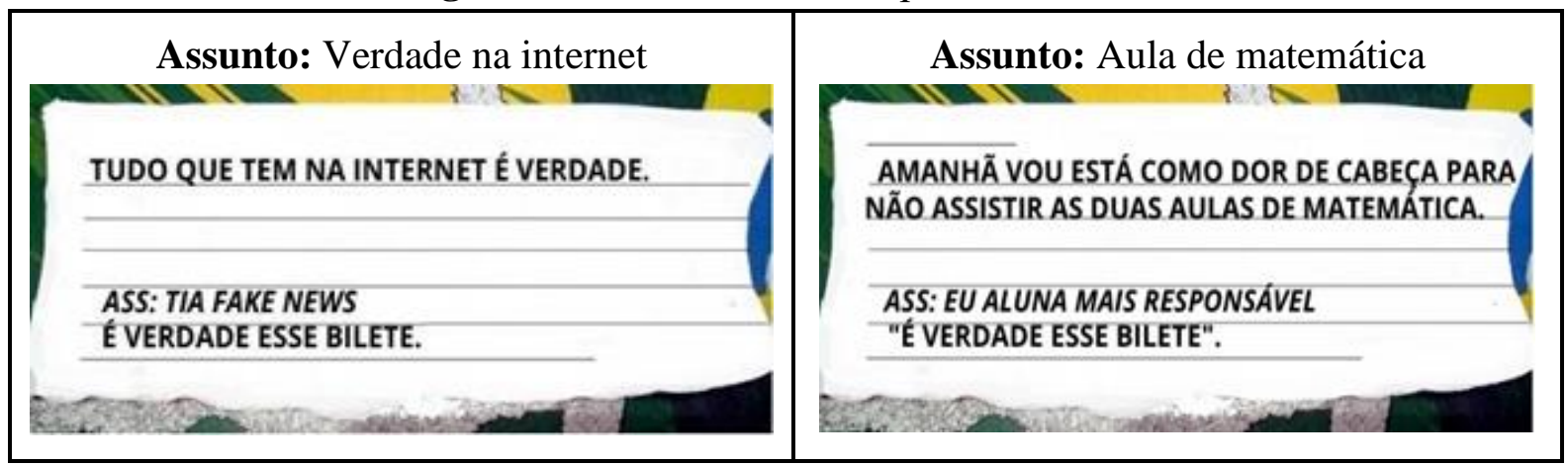

Fonte: acervo da pesquisa 


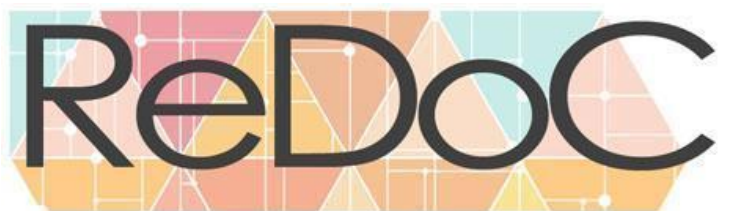

\section{Revista Docência e Cibercultura}

É possível inferir que esse meme tenha sido elaborado para problematizar um pensamento ou replicar um discurso já bem disseminado em relação à temática: é preciso checar, avaliar a fonte, o conteúdo, a data de publicação, pesquisar em outros sites/mídias etc. antes de aceitar como verdade uma informação.

Todavia, o meme "Aula de matemática" nos faz refletir sobre as metodologias utilizadas, muitas vezes, no ensino dessa disciplina: memorizar regras, decodificar fórmulas, aula baseada em um modelo transmissão-recepção, o que gera distanciamento entre os estudantes e o sistema de ensino. Também, destaca-se a composição estrutural que ainda vigora nas escolas, marcadas pela disciplina e pelo controle, representadas pelas carteiras enfileiradas, campainha delimitando o início e o final das atividades, instrução em massa, processos centrados na autoridade do professor/a etc., configurando, assim, a chamada educação fabril (SACRISTÁN, $1985)^{8}$. Essas significações fazem pouco sentido para a geração atual, que vive o paradigma da ubiquidade, a partir das múltiplas possibilidades de interação e de comunicação em redes.

Repensar o trabalho com a linguagem no desenvolvimento de práticas pedagógicas que dialoguem com as práticas sociais dos estudantes se torna um desafio quando presumimos que esse trabalho leve os alunos a tomar uma atitude crítica em relação aos textos e à sua visão de mundo perante a realidade. Considerando, também, a multiplicidade de textos visuais com os quais nos deparamos diariamente e que nos levam à reflexão por sua forma, cores, ironia ou quaisquer outros atrativos inerentes à imagem, é que Cope e Kalantzis (2006) propõem que os professores atuem como designers do conhecimento; ou seja, pessoas que projetam processos e ambientes para a aprendizagem, repensando continuamente sua prática.

A construção de significado é uma atividade de renegociação dos processos de designers, que se refaz na busca de novas unidades de sentido, possibilitando a criação de novos formatos, novos textos, novas culturas textuais. Nesse sentido, o gênero discursivo memes de internet,

\footnotetext{
${ }^{8}$ A educação fabril corresponde a uma situação apresentada por Gimeno Sacristán (1985) em que a dinâmica existente na escola é assemelhada a de uma indústria. Ampliando essa concepção, Toffler (1970) aponta alguns artefatos presentes na escola, como a campainha, a sincronização, a concentração num edifício fechado, as classes e a separação por idades, as classes sociais (professores - alunos) como exemplo de uma educação mecanicista, cujo principal objetivo seria a inserção do aluno no mercado de trabalho.
} 
por todo seu potencial crítico-reflexivo, podem configurar-se como práticas textuais no espaço escolar que oportunizam a formação do hiperleitor na cultura digital.

\section{Considerações finais}

Como atividade de interação altamente complexa de produção de sentidos, a leitura dos textos na esfera digital requer intervenção específica para o domínio de compreensão, papel que cabe ao professor e à instituição escolar. Entretanto, a dissonância entre a pedagogia escolar e as experiências de aprendizagem que envolvem essas práticas, que ocorrem em muitos momentos na sala de aula, não tem correspondido, satisfatoriamente, à necessidade de ampliação de repertório do conhecimento desses leitores, neste estudo considerados como hiperleitores.

Entendemos que o conhecimento acontece por intermédio das formulações discursivas realizadas pelas enunciações dos sujeitos. Assim, a formação do sujeito-autor (BAKHTIN, 2003) - um dos objetivos das práticas de linguagem realizadas no âmbito escolar - concede aos alunos a oportunidade de concretizar e materializar o pensamento por intermédio da enunciação da linguagem.

Por conta da prática de leitura, muitas vezes, concentrar-se na superfície do texto, alguns leitores não conseguem, por exemplo, distinguir notícias falsas de fatos, o que requer que o letramento crítico seja uma ação cada vez mais valiosa na formação de professores e de estudantes para o uso consciente de informações que circulam nos espaços digitais.

Aludimos, então, que o trabalho com memes de internet no contexto de sala de aula, se tomado de maneira crítica, pode mobilizar um melhor entendimento da participação dos estudantes em espaços virtuais, a partir de gêneros discursivos híbridos e convergentes. De fato, pedagogicamente, essas práticas são importantes e têm implicações para a formação dialógicodiscursivo dos alunos.

Os desdobramentos deste estudo foram fundantes para lograr uma atitude que valorize aprendizagem experiencial com práticas e saberes do ensino de leitura e de produção textual, em que os memes se figuraram como gêneros discursivos centrais e fundantes. Já a escola, como instituição para a qual os interesses da sociedade se voltam, precisa estimular o 


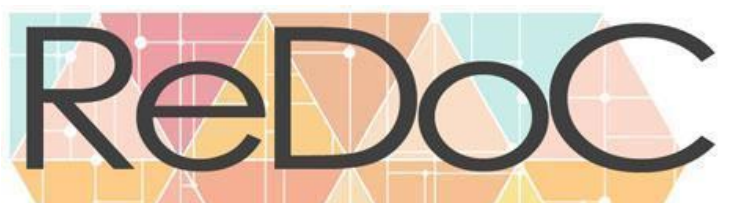

\section{Revista Docência e Cibercultura}

protagonismo dos estudantes, para o desenvolvimento de uma consciência crítica e criativa perante a cidadania no ciberespaço.

\section{REFERÊNCIAS}

ALVES FILHA, Isnalda Berger. Gêneros memes de internet: ampliando ações discursivas e multimodais em esferas públicas digitais (Dissertação de Mestrado em Estudos Linguísticos). Universidade Estadual de Feira de Santana - UEFS, 2018.

BAKHTIN, Mikhail. Os gêneros do discurso. In: Estética da criação verbal. São Paulo: Martins Fontes, 2003. p. 261-306.

BRASIL. Parâmetros Curriculares Nacionais: língua portuguesa/Secretaria de Educação Fundamental. - Brasília: 1997.

COPE, Bill.; KALANTZIS, Mary. (Orgs). Multiliteracies: Literacy Learning and the Design of Social Futures. London/New York: Routledge, 2006 [1996].

DAWKINS, Richard. O gene egoísta. Tradução de Rejane Rubino. São Paulo: Companhia das Letras, 1976.

FREIRE, Paulo. Pedagogia da autonomia: saberes necessários à prática educativa. São Paulo: Paz e Terra, 1996.

KRESS, Gunther; LEEUWEN, Theo van. Reading images: the gramar of visual design. Taylor and Francis, 2006 [1996].

LANKSHEAR, Colin; KNOBEL, Michele. New Literacies: Everyday Practices and Classroom Learning. 2 ed. Maidenhead and New York: Open University Press, 2006.

LÉVY, Pierre. O que é virtual? Trad. Paulo Neves. São Paulo, Ed. 34, 1996.

LÉVY, Pierre. Cibercultura. São Paulo: Ed. 34, 1999.

MACIEL, Ruberval Franco; TAKAKI, Nara Hiroko. Novos Letramentos pelos Memes: Muito além do ensino de línguas. Revista Contextuais, 2011.

MONTE MÓR, Walkyria. Crítica e letramentos críticos: reflexões preliminares. In: ROCHA, Claudia.; MACIEL, Ruberval (orgs). Língua estrangeira e formação cidadã: por entre discursos e práticas. Campinas-SP: Pontes, 2015.

OLIVEIRA, Maria Marly de. Como fazer pesquisa qualitativa. 4 ed. Petrópolis, RJ: Editora Vozes, 2012.

\begin{tabular}{r|l|l|l|l|l|l}
\hline (C) Redoc & Rio de Janeiro & v. 5 & n.1 & p. 136 & Jan/Abr 2021 & ISSN 2594-9004 \\
\hline
\end{tabular}




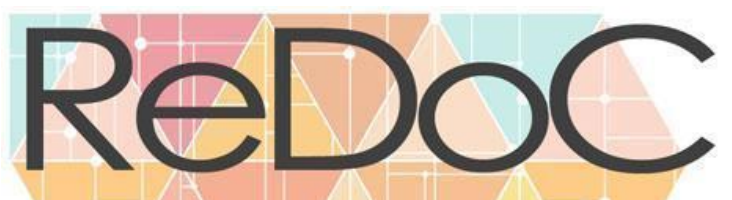

\section{Revista Docência e Cibercultura}

OLIVEIRA, Maria Marly. Sequência didática interativa no processo de formação de professores. Petrópolis, RJ: Vozes, 2013.

RECUERO, Raquel. Redes sociais na internet. Porto Alegre: Sulina, 2009.

RICOEUR, Paul. O conflito das interpretações: ensaios de hermenêutica. Rio de Janeiro: Imago, 1978.

ROJO, Roxane (org.). Escola conectada: os multiletramentos e as TICs. São Paulo: Parábola, 2013.

SACRISTÁN, Gimeno. La pedagogia por objetivos: obsesión por la eficiencia. Madrid: Morata, 1985.

SANTAELLA, Lucia. Matrizes da linguagem e pensamento: sonora, visual, verbal. São Paulo: Iluminuras/Fapesp, 2001.

SANTAELLA, Lucia. Navegar no ciberespaço: o perfil cognitivo do leitor imersivo. São Paulo: Paulus, 2004.

SILVA, Maria Jeane Souza de Jesus; SANTANA, Neidson Dionísio Freitas; ANECLETO, Úrsula Cunha. Letramento digital crítico e formação do leitor na cultura digital: algumas considerações. Hipertextus Revista Digital, v.20, Julho, 2019. Disponível em: www.hipertextus.net. Acessado em: 21 jul. 2020.

TAKAKI, Nara. Letramentos na sociedade digital: navegar é e não é preciso. Jundiaí: Paco Editorial, 2012.

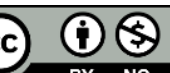

Este é um artigo de acesso aberto distribuído sob os termos da Licença Creative Commons Atribuição Não Comercial-Compartilha Igual (CC BY-NC- 4.0), que permite uso, distribuição e reprodução para fins não comerciais, com a citação dos autores e da fonte original e sob a mesma licença.

\begin{tabular}{r|l|l|l|l|l|l}
\hline (C) Redoc & Rio de Janeiro & v. 5 & n.1 & p. 137 & Jan/Abr 2021 & ISSN 2594-9004 \\
\hline
\end{tabular}

